\title{
PROCESSO DESAPROPRIATÓRIO: a destinação dos bens e a ocorrência do instituto jurídico da tredestinação
}

\author{
Leiner Marchetti PEREIRA ${ }^{1}$
}

Recebido em: 16/04/2016 - Aprovado em: 29/06/2016 - Disponibilizado em: 30/07/2016

\begin{abstract}
RESUMO:
$\mathrm{O}$ artigo tem como objetivo o estudo do rito procedimental da desapropriação, analisando o instituto jurídico sob o ponto de vista de uma teoria crítica do direito, coadunando-se com realidade fática. Será realizada a análise do assunto com ênfase nos pressupostos da desapropriação, utilidade pública, necessidade pública ou interesse social, nos exatos termos da previsão constante na Constituição da República, aliada a uma análise detida da destinação dos bens a serem desapropriados, culminando-se, portanto, no exame da tredestinação lícita, diferenciando-a da tredestinação ilícita. Este trabalho será desenvolvido mediante pesquisas doutrinárias e jurisprudenciais que gravitam sobre a temática. O objetivo desta pesquisa é a análise do procedimento da desapropriação em conformidade com a previsão constitucional do instituto, rechaçando-se qualquer destinação para o bem desapropriado contrária àquela prevista no ato expropriatório, de forma a assegurar o interesse público na prática do ato, repelindo, portanto, eventuais desvios de finalidade. A presente pesquisa evidenciou a preocupação dos juristas e tribunais pátrios na mantença do interesse público nos atos de desapropriação levado a cabo pelo Poder Público, evitando-se o abuso de poder e atitudes contrárias aos princípios que norteiam a Administração Pública.
\end{abstract}

PALAVRAS-CHAVE: Direito de Propriedade. Desapropriação. Tredestinação.

\section{EXPROPRIATION PROCESS: the destination of the goods and the occurrence of the legal institution of tredestinação}

\begin{abstract}
:
The article aims to study the procedural rite of dispossession, analyzing the legal institution from the point of view of a critical theory of law, and is in line with objective reality. Will be held the subject of analysis with emphasis on assumptions of expropriation, public utility, public need or social interest, the exact terms of the constant provision in the Constitution of the Republic, together with a detailed analysis of the allocation of property to be expropriated, ending up, therefore, when examining the lawful tredestinação, differentiating it from illicit tredestinação. This work will be developed by doctrinal and jurisprudential research gravitating on the subject. The objective of this research is the analysis of the expropriation procedure in accordance with the constitutional provision of the institute, refusing to any destination for the good expropriated contrary to that provided for in the Expropriation Act, to ensure the public interest in the performance of the act, repelling, therefore, any changes in purpose. This research showed the concern of lawyers and patriotic courts in maintenance of the public interest in the acts of expropriation carried out by the Government, avoiding the abuse of power and attitudes contrary to the principles governing public administration.
\end{abstract}

KEYWORDS: Property Law. Expropriation. Tredestinação.

\footnotetext{
${ }^{1}$ Advogado, Professor Universitário, Coordenador de Curso. Mestre em Direito pela Universidade Vale do Rio Verde UNINCOR. E-mail: leinermarchetti@ hotmail.com 


\section{Introdução}

O presente trabalho descreve a natureza do procedimento da desapropriação, elucidando suas características de forma a conceituar o instituto, demonstrando de maneira efetiva uma das formas de intervenção do Estado na propriedade, diante de sua ação na esfera individual, com a substituição paulatina do Estado liberal pelo Estado de bem-estar social, voltado para a prestação de serviços efetivos para a coletividade.

Tal abordagem se justifica na defesa do interesse público, condicionando o uso da propriedade particular em estrita observância aos procedimentos autorizados na Constituição e nas leis reguladoras, sob pena de incorrer o Estado em conduta totalmente ilegítima em afronta aos direitos individuais dos cidadãos.

É importante ressaltar a contribuição deste trabalho para os profissionais que atuam na Administração Pública, gerindo a res publica, de forma a não desvirtuar e não utilizar de forma nefasta um dos procedimentos pelo qual o Estado intervém na propriedade privada condicionando o exercício de direitos individuais em prol da coletividade, do interesse público.

$$
\text { O objetivo desta pesquisa é o }
$$
aprofundamento acerca da destinação dos bens objeto de desapropriação, destinação esta que jamais poderá afastar-se dos fundamentos constitucionais da intervenção do Estado na propriedade particular: a função social da propriedade e a prevalência do interesse público, ensejando, pois, a ocorrência do fenômeno da tredestinação lícita.

Este propósito será alcançado por intermédio da revisão bibliográfica sobre o assunto aliado a análise jurisprudencial do tribunais acerca do tema proposto.

\section{Regramento Constitucional}

A Carta Magna autoriza a intervenção do Estado na propriedade, ao mesmo tempo em que assegura o direito individual à propriedade (art. $5^{\circ}$, incisos XXII, XXIII ${ }^{2}$ ). Noutro giro, condiciona o uso desse direito ao atendimento da função social da propriedade, que, acaso não atendida, autoriza o Estado a intervir para, se for o caso, forçar o seu atendimento (art. 182, $\S 2^{\circ}$ da Constituição da República ${ }^{3}$ ).

O legislador constituinte também previu restrições impostas ao particular em caso de

\footnotetext{
${ }^{2}$ Art. $5^{\circ}(\ldots)$

XXIII - a propriedade atenderá a sua função social;

XXIV - a lei estabelecerá o procedimento para desapropriação por necessidade ou utilidade pública, ou por interesse social, mediante justa e prévia indenização em dinheiro, ressalvados os casos previstos nesta Constituição;

3 Art. 182. A política de desenvolvimento urbano, executada pelo Poder Público municipal, conforme diretrizes gerais fixadas em lei, tem por objetivo ordenar o pleno desenvolvimento das funções sociais da cidade e garantir o bem- estar de seus habitantes.

(...)

$\S 2^{\circ}$ A propriedade urbana cumpre sua função social quando atende às exigências fundamentais de ordenação da cidade expressas no plano diretor.
} 
não observância das regras estabelecidas no plano diretor do Município (Lei Federal $\mathrm{n}^{\circ}$ 10.257/01- Estatuto da Cidade) acerca da função social da propriedade, sendo que dentre tais restrições podem ser citadas a obrigação de promover o adequado aproveitamento do solo urbano não edificado, subutilizado ou não utilizado, bem como o parcelamento e edificação compulsórios e por fim, como medida mais drástica, a desapropriação (art. 182, $\$ 4^{\circ}$, da Constituição da República ${ }^{4}$ ).

Nesse sentido prelecionam Marcelo Alexandrino e Vicente Paulo (2010, pág. 911), ao mencionar os ensinamentos do Professor José dos Santos Carvalho Filho, senão veja: “(...) a função social pretende erradicar algumas deformidades existentes na sociedade, nas quais o interesse egoístico do indivíduo põe em risco os interesses coletivos".

Diante da diversidade dos fins almejados pelo Estado, sempre na defesa do interesse público visado, são diversos os meios

\footnotetext{
${ }^{4}$ Art. $182(\ldots)$

$\S 4^{\circ}$ É facultado ao Poder Público municipal, mediante lei específica para área incluída no plano diretor, exigir, nos termos da lei federal, do proprietário do solo urbano não edificado, subutilizado ou não utilizado, que promova seu adequado aproveitamento, sob pena, sucessivamente, de:

I - parcelamento ou edificação compulsórios;

II - imposto sobre a propriedade predial e territorial urbana progressivo no tempo;

III - desapropriação com pagamento mediante títulos da dívida pública de emissão previamente aprovada pelo Senado Federal, com prazo de resgate de até dez anos, em parcelas anuais, iguais e sucessivas, assegurados o valor real da indenização e os juros legais.
}

de intervenção na propriedade, sendo classificados como restritivos ou supressivos.

$\mathrm{Na}$ intervenção restritiva o Estado limita-se a impor restrições e condicionamentos ao uso da propriedade sem retirá-la de seu proprietário. A contrário sensu, na intervenção supressiva o Estado transfere coercitivamente para si a propriedade de terceiro, inserindo-se em tal modalidade de intervenção a desapropriação.

Assim sendo, a desapropriação configura-se como o meio mais gravoso de intervenção do Estado na propriedade, subtraindo esta do domínio do proprietário e inserindo-a no patrimônio do Estado, possuindo como postulado a supremacia do interesse público sobre o privado.

Cumpre ainda mencionar que a competência para legislar sobre direito de propriedade, e, por conseguinte, desapropriação, é privativa da União $(\mathrm{CR} / 88$, art. 22, incisos I, II e III, especificadamente o inciso II). Porém, tal competência refere-se apenas à regulação da matéria, não devendo, pois, ser confundida com a competência administrativa, sendo que esta é repartida entre todos os entes federados, ou seja, a todos incumbe $o$ poder de restrição e condicionamento do uso da propriedade. 


\section{Do Instituto da Desapropriação}

De acordo com os ensinamentos de Marcelo Alexandrino e Vicente Paulo (2009, pág. 137), assim pode-se definir o instituto da desapropriação como o: “ (...) procedimento de direito público pelo qual o Poder Público transfere para si a propriedade de terceiro, por razões de utilidade pública, de necessidade pública ou de interesse social, normalmente mediante o pagamento de justa e prévia indenização".

Corroborando tal entendimento doutrinário, é a previsão da Carta Constitucional, em seu art. $5^{\circ}$, inciso XXIV, “in verbis":

XXIV - a lei estabelecerá o
procedimento
desapropriação para
necessidade ou utilidade
pública, ou por interesse
social, mediante justa e
prévia indenização em
dinheiro, ressalvados os
casos previstos nesta
Constituição.

Acerca do instituto da desapropriação, assevera Alexandre de Moraes (2002, págs. 266/267) sobre a possibilidade de relativização do direito à propriedade privada, senão veja:

A transformação que a ideia de um Estado social introduz no conceito de direito à propriedade privada, ao assinalar uma função social com efeitos delimitadores de seu conteúdo, e as complicações cada vez mais frequentes da vida moderna, especialmente no setor econômico, determinaram uma importante revisão do instituto da desapropriação, que se converteu, de limite negativo do direito absoluto de propriedade, em instrumento positivo posto à disposição do poder público para o cumprimento de suas finalidades de ordenação e conformação da sociedade a imperativos crescentes de justiça social, diante dos quais o direito de propriedade perde suas características clássicas de absolutismo e exclusividade.

Trata-se de forma originária de aquisição da propriedade, pois não provém de nenhum título anterior, e, portanto, o bem desapropriado torna-se insuscetível de reivindicação e libera-se de quaisquer ônus que incidissem sobre o mesmo, sendo que ocorre a sub-rogação de eventuais credores sobre o preço.

A desapropriação poderá efetivar-se mediante procedimento administrativo ou judicial. O procedimento administrativo iniciase com a manifestação do Poder Público pelo interesse na desapropriação do bem, sendo iniciado o processo tendente a transferência do bem para o patrimônio público. Tal procedimento administrativo encerra-se sem necessidade de intervenção do Poder Judiciário por intermédio do Estado- Juiz, caso haja acordo entre particular e a Administração 
Pública, sendo denominada desapropriação amigável.

Porém, diante da inexistência de acordo, torna-se imprescindível a intervenção judicial, então será submetido ao magistrado a solução da controvérsia existente.

Torna-se relevante mencionar os pressupostos da desapropriação, sendo: a utilidade pública ou necessidade pública, bem como o interesse social.

Ocorre a utilidade pública quando se verifica conveniente a transferência do bem para o Poder Público, embora não seja imprescindível, a exemplo, da desapropriação de um imóvel para a construção de uma escola.

Já a necessidade pública configura-se diante de situações emergenciais nas quais a transferência deve ser realizada de forma imediata, ante a urgência do Poder Público na utilização do bem, como é o caso de ocorrência de calamidade pública.

No que concerne ao interesse social, tal modalidade de desapropriação volta-se para a necessidade de cumprimento da função social da propriedade, privilegiando seu melhor aproveitamento em benefício da coletividade, como ocorre na desapropriação de terras rurais para fins de reforma agrária.

Diante de uma análise dos pressupostos da desapropriação supracitados, conclui-se que quando o bem expropriado para um fim é empregado noutro sem utilidade pública ou interesse social, dá ensejo ao desvio de finalidade, como assevera Hely Lopes Meirelles (2009, pág.628), na obra Direito Administrativo Brasileiro, in verbis:

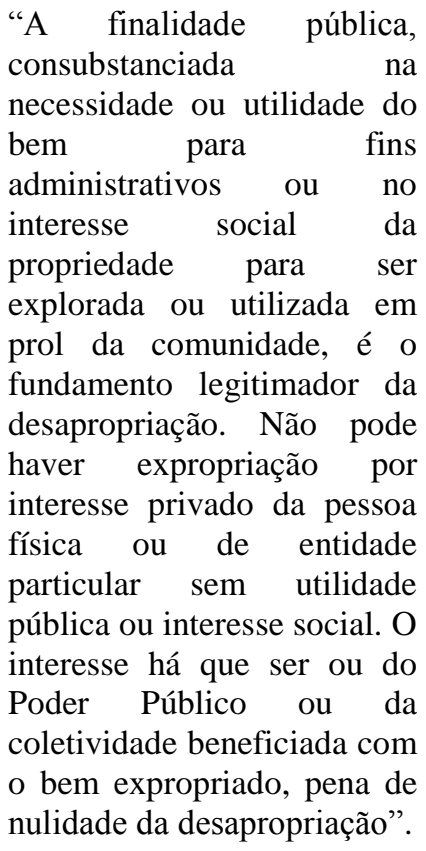

Nesse diapasão, os bens desapropriados por necessidade pública ou interesse público possuem como finalidade pública sua destinação que deve ser voltada ao suprimento dos interesses públicos, especialmente no que se refere às obras e serviços públicos.

Logo, no que tange aos bens expropriados por interesse social, estes possuem como finalidade pública sua destinação a particulares que irão explorá-los ou utilizá-los para atendimento de interesses da comunidade e não do Poder Público. 
Neste sentido é o magistério de Hely Lopes Meirelles (2009, p. 628), onde afirma que: "A desapropriação por necessidade ou utilidade pública dá atendimento a atividades administrativas; a desapropriação por interesse social visa a solucionar problemas de bem-estar social. Ambas têm finalidade pública, mas com objetivos e características diferentes".

Desta forma, o bem expropriado, via de regra, não poderá sofrer desvio de destinação, instituto jurídico denominado tredestinação, onde se evidencia a ocorrência do desvio de destinação ou mau emprego do bem expropriado. Como visto, o instituto expropriatório não pode perder de vista que sua finalidade é sempre pública, podendo em alguns casos ser até genérica, caso em que o bem desapropriado para um fim público poderá ser utilizado para outra finalidade pública, não ocorrendo, nesta situação, o desvio de finalidade.

\section{Da Tredestinação}

A tredestinação é entendida no âmbito do direito administrativo como o instituto jurídico concernente à destinação desconforme, diferente daquela inicialmente prevista no ato administrativo.

A doutrina prevê duas hipóteses de tredestinação, uma denominada lícita e outra ilícita. Verifica-se a tredestinação lícita quando

mantida a finalidade de interesse público, o Poder Público dá ao bem desapropriado destino diverso do inicialmente planejado, a exemplo do que ocorre se o Município desapropriar uma área para a construção de uma creche e, devido ao interesse público posterior vir a construir um hospital na referida área, conforme elucida Fernanda Marinela (2011, pág. 904) em sua festejada obra:

Considera-se tredestinação
lícita quando, apesar da
mudança, persistir uma razão
de interesse público para
justificar o ato. (...) Os
Tribunais têm entendido que
não há desvio de finalidade
se o bem foi aplicado para
algum outro fim público,
ainda que diverso do alegado
na desapropriação, o que
caracteriza uma mudança de
finalidade autorizada pelo
ordenamento jurídico.

Sobre a tredestinação lícita assim é o posicionamento do colendo Superior Tribunal de Justiça - STJ, senão veja alguns acórdãos relevantes:
MUNICÍPIO DE CUBATÃO. TREDESTINAÇÃO LÍCITA. RETROCESSÃO. INOCORRÊNCIA

1. O Tribunal de origem, ao avaliar o conteúdo fático probatório dos autos, concluiu que não houve retrocessão, pois o imóvel recebeu destinação pública relevante. 2. A discussão sobre eventual cláusula de renúncia ao direito de preempção inserida 
em escritura pública de desapropriação amigável se mostra inócua após constatada a não ocorrência da retrocessão.

3. Recurso especial não provido.

(...)

Todavia, o aresto recorrido entendeu ter havido tredestinação lícita, que no dizer peculiar de José dos Santos Carvalho Filho, ocorre "quando, persistindo o interesse público, o expropriante dispense ao bem desapropriado destino diverso do que planejara no início" (Manual de Direito Administrativo. 20. ed. Rio de Janeiro: LumenJuris. 2008. p. 822).

Oportuno colacionar o seguinte excerto do aresto:

"a modificação da finalidade imposta pela Municipalidade não dá direito a retrocessão pois ainda permanece o interesse público, mesmo com a celebração do contrato de concessão real de uso mencionado na inicial, e eventual pagamento de indenização por perdas e danos importaria em enriquecimento ilícito para os autores".(Resp $\mathrm{N}^{\mathrm{o}}$ 814.570 - SP, Relator: Ministro Mauro Campbell Marques, Segunda Turma, DJ: 17/08/2010).

ADMINISTRATIVO - DESAPROPRIAÇÃO - UTILIDADE PÚBLICA TREDESTINAÇÃO LÍCITA - RETROCESSÃO E PREEMPÇÃO - RENÚNCIAEXPRESSA A ESSE DIREITO - POSSIBILIDADE - FINALIDADE PÚBLICARECONHECIDA NA INSTÂNCIA ORDINÁRIA - SÚMULA 07/STJ -ANÁLISE DE CLÁUSULAS CONTRATUAIS SÚMULA 05/STJ DIVERGÊNCIA JURIS-
PRUDENCIAL - FALTA DE IDENTIDADE DAS BASES FÁTICAS DOS ACÓRDÃOS CONFRONTADOS.

1. O Juiz de Direito sentenciante, afastando a prescrição alegada, houve por bem indeferir o pedido, sob o fundamento de que ocorreu tredestinação lícita, atingido fim público, pois, no lugar do parque ecológico foi implementado pólo industrial metal-mecânico, com terminal intermodal rodoviário de cargas e centro de pesquisa ambiental, inclusive com geração de empregos, além do que era descabido o pedido de retrocessão porque o bairro onde situado o imóvel já não era mais área residencial. (...)

(REsp 975.599/SP, Rel. Min. Humberto Martins, Segunda Turma, DJe 07/03/2008).

Ao contrário, conforme entendimento doutrinário, ocorre a tredestinação ilícita quando o Poder Público transfere a terceiro o bem desapropriado ou pratica desvio de finalidade, permitindo que alguém se beneficie da utilização, reconhecendo-se ao expropriado o direito a uma satisfação jurídica diante de tal fato, ensejando a possibilidade de o expropriado se socorrer do instituto da retrocessão, ou seja, se o expropriante não atribui ao bem uma finalidade pública, nasce uma pretensão ao expropriado circunstanciada pela retrocessão.

Nesse diapasão, prossegue o referido doutrinador (2009, pág. 884) conceituando o 
instituto da retrocessão como "um direito real, o do ex- proprietário de reaver o bem expropriado, mas não preposto a finalidade pública”.

Acerca da tredestinação ilícita, assim tem se posicionado o colendo Superior Tribunal de Justiça - STJ, in verbis:

ADMINISTRATIVO. RETROCESSÃO. DESTINAÇÃO DE PARTE DO IMÓVEL DESAPROPRIADO À CONSTRUÇÃO DA SEDE DA ASSOCIAÇÃO DOS SERVIDORES DO ENTE EXPROPRIANTE. TREDESTINAÇÃO ILÍCITA. AUSÊNCIA DE UTILIDADE PÚBLICA. INDENIZAÇÃO POR PERDAS E DANOS.

1. A utilização de parte do imóvel desapropriado como sede da associação dos servidores do ente expropriante, reservada à recreação e lazer de seus associados, constitui tredestinação ilícita que torna cabível a retrocessão diante da ausência de utilidade pública da desapropriação.

(...)

3. Recurso especial provido. (Resp. 647340 / SC, Relator: Ministro João Otávio de Noronha, Segunda Turma, DJ:06/04/2006).

PROCESSUAL CIVIL E ADMINISTRATIVO.

REINTEGRAÇÃO DE POSSE. AUTORES QUE CONSEGUIRAM A RETROCESSÃO DE IMÓVEL. TREDESTINAÇÃO ILÍCITA. OCORRÊNCIA. ILEGITIMIDADE ATIVA.
MATÉRIA TRANSITADA EM JULGADO.

(...)

2. O Município de Paranaíba-MS desapropriou a área em 1999. Em seguida, autorizou a exploração da atividade extrativista pelo recorrente. Ocorre que os proprietários (recorridos) propuseram Ação de Retrocessão, pois teria havido desvio de finalidade na desapropriação. $\mathrm{O}$ Município resolveu firmar acordo com os antigos proprietários e reconheceu seus direitos de domínio e posse sobre a área. $\mathrm{O}$ recorrido impugna a retrocessão e aponta ilegitimidade ativa dos recorridos.

(...)

4. As instâncias de origem aferiram que o recorrente corrompeu o então Prefeito para que desapropriasse a área em litígio e a concedesse para exploração.

5. O direito à retrocessão (art. 519 do CC, equivalente ao art. 1.150 do CC/1916), ou seja, o direito de o antigo proprietário reaver o imóvel expropriado, dá-se em caso de grave desvio de finalidade no ato estatal (tredestinação ilícita).

6. Difícil imaginar exemplo mais evidente de tredestinação ilícita, porquanto a desapropriação e a outorga do imóvel ao recorrido decorreram de pagamento ilícito ao então Prefeito.

(...)

10. Recurso Especial não provido. (Resp 1134493, Relator: Ministro Herman Benjamim, Segunda Turma DJ: 15/12/2009). 
Diante da análise dos julgados colacionados, torna-se mister a abordagem do instituto da retrocessão, como corolário lógico da tredestinação ilícita, permitindo-se, pois, ao ex- proprietário intentar ação visando reaver seu imóvel, restituindo a importância recebida, indenizando as benfeitorias que porventura tenham sido realizadas pelo expropriante acaso não exista a finalidade pública que desencadeou o ato expropriatório.

\section{Da Retrocessão}

Abordar-se-á, no presente tópico o instituto jurídico da retrocessão, assim definido como a obrigação do expropriante de oferecer o bem ao expropriado, quando o bem tiver destinação diferente da declarada, mediante a devolução do valor da indenização recebido. Conforme dicção contida no art. 35, do Decreto-lei 3.365/41, caso não haja a retrocessão nesta hipótese, o direito do expropriado se resolve em perdas e danos, ante a impossibilidade de bem incorporado ao patrimônio público ser objeto de reivindicação por particular.

A retrocessão é, pois, considerada por parte da doutrina pátria, a exemplo de Hely Lopes Meirelles, como obrigação pessoal de devolver o bem e não um direito real inerente ao bem, em contraposição a outra parcela de estudiosos, a exemplo de Celso Antônio
Bandeira de Mello, onde afirmam ter a retrocessão a natureza de direito real, posicionamento este corroborado pelo colendo Superior Tribunal de Justiça - STJ e Excelso Supremo Tribunal Federal- STF, conforme acórdãos abaixo transcritos:

DIREITO ADMINISTRATIVO - RECURSO ESPECIAL - RETROCESSÃO DESVIO DE FINALIDADE PÚBLICA DE BEM DESAPROPRIADO - DECRETO EXPROPRIATÓRIO. CRIAÇÃO DE PARQUE ECOLÓGICO. NÃO EFETIVAÇÃO. BENS DESTINADOS AO ATENDIMENTO DE FINALIDADE PÚBLICA DIVERSA. TREDESTINAÇÃO LÍCITA. INEXISTÊNCIA DE DIREITO À RETROCESSÃO OU À PERDAS E DANOS.

(...)

2. A retrocessão constitui-se direito real do exproprietário de reaver o bem expropriado, mas não preposto a finalidade pública (Celso Antônio Bandeira de Mello, Curso de Direito Administrativo, $17^{\mathrm{a}}$ edição, pg. 784). 3. Precedentes: RESP n. ${ }^{\circ}$ 623.511/RJ, Primeira Turma, deste relator, DJ de 06.06.2005) RESP ${ }^{\circ}$ 570.483/MG, Segunda Turma, Rel. Min. Franciulli Netto, DJ de 30.06.2004).

4. Outrossim, o Supremo Tribunal Federal também assentou a natureza real da retrocessão: "DESAPROPRIAÇÃO - Retrocessão - Prescrição - Direito de natureza real - Aplicação do prazo previsto no art. 177 do $\mathrm{CC}$ e não do quinquenal do De. 20.910/32 - Termo inicial Fluência a partir da data da 
transferência do imóvel ao domínio particular, e não da desistência pelo Poder expropriante." (STF, ERE 104.591/RS, Rel. Min. Djaci Falcão, DJU 10/04/87)

5. Consagrado no Código Civil, o direito de vindicar a coisa, ou as conseqüentes perdas e danos, forçoso concluir que a lei civil considera esse direito real, tendo em vista que é um sucedâneo do direito à reivindicação em razão da subtração da propriedade e do desvio de finalidade na ação expropriatória. (STJ, REsp 868120 / SP Relator: Ministro Luiz Fux, Primeira Turma, DJ: 27/11/2007).

Tais discussões doutrinárias gravitam em torno da análise do art. $519^{5}$ do Código Civil que estabelece que se a coisa expropriada para fins de necessidade ou utilidade pública, ou por interesse social, não tiver o destino para que se desapropriou, ou não for utilizada em obras ou serviços públicos, caberá ao expropriado direito de preferência, pelo preço atual da coisa. Além do mais, a questão também envolve o disposto no art. $35^{6}$ do Decreto-lei $n^{\circ}$ 3.365, de 21-06-41 que prevê que os bens expropriados, uma vez incorporados à Fazenda

5 Art. 519. Se a coisa expropriada para fins de necessidade ou utilidade pública, ou por interesse social, não tiver o destino para que se desapropriou, ou não for utilizada em obras ou serviços públicos, caberá ao expropriado direito de preferência, pelo preço atual da coisa.

${ }^{6}$ Art. 35. Os bens expropriados, uma vez incorporados à Fazenda Pública, não podem ser objeto de reivindicação, ainda que fundada em nulidade do processo de desapropriação. Qualquer ação, julgada procedente, resolver-se-á em perdas e danos.
Pública, não podem ser objeto de reivindicação, ainda que fundada em nulidade do processo de desapropriação, sendo pois, resolvida em perdas e danos qualquer ação nesse sentido julgada procedentes, levando, pois, tais artigos de lei à formação do convencimento de inúmeros doutrinadores acerca do caráter de direito pessoal da retrocessão.

Já em contraposição a tal posicionamento, os defensores da natureza de direito real da retrocessão firmam tal entendimento em virtude da previsão constitucional do art. $5^{\circ}, \mathrm{XXIV}$, ou seja, desaparecendo a finalidade pública da desapropriação com a desistência da aplicação do bem ao destino, justificaria a expropriação, sendo plausível o retorno do bem ao exproprietário, ante a insubsistência do fundamento constitucional que a autorizaria.

Assim, padece de inconstitucionalidade leis que afrontem o exercício do direito de propriedade assegurado constitucionalmente, direito este apenas restringido quando existe a finalidade pública da desapropriação de acordo com os requisitos da necessidade ou utilidade pública, ou por interesse social.

Isso não quer dizer que não é constitucional a aplicação do disposto nos arts. 518 e 519 do Código Civil, sendo, pois, assegurado ao ex-proprietário o direito de preferência, pleiteando perdas e danos caso aliene o bem sem oferecer ao expropriado para que exerça seu 
direito de prelação; caso não opte pelo exercício do direito de retrocessão assegurado constitucionalmente. Porém, cumpre ressaltar que o exercício de um direito exclui o outro, conforme assevera Celso Antônio Bandeira de Mello (2009, pág. 889):

O que não poderia, a toda evidência, é pretender simultaneamente o desfrute dos dois direitos, pois o exercício de um exclui o exercício do outro. Há, simplesmente, dois direitos, alternativamente, isto é, excludentemente, postos à disposição do expropriado. Um que advém diretamente da Constituição; outro que lhe foi outorgado pelo Código Civil.

Portanto, conclui-se que sendo exercido o direito de preferência pelo expropriado, o preço a ser pago é o preço atual da coisa (art. 519 CC), sendo que tal direito deve ser exercido no prazo de 60 (sessenta) dias a contar da data em que o Poder Público houver notificado o ex-proprietário para tanto. Insta, ainda, ressaltar que o prazo para intentar ação pleiteando perdas e danos, uma vez violado o direito de preferência é de 05 (cinco) anos, nos termos do disposto no art. $1^{\circ}$ do Decreto Federal $\mathrm{n}^{\circ}$ 20.910, de 6.1.32.

Outrossim, o prazo prescricional para reaver o bem é de 10 anos (art. 205 CC) para alguns doutrinadores e 15 anos para outros, sendo este último o prazo da usucapião, inde- pendentemente de justo título e boa-fé, conforme art. 1238 caput do Código Civil, conforme preleciona Celso Antônio Bandeira de Mello (2009, pág. 893/894), in verbis:

Hoje, sob o império do atual Código Civil, a prescrição não mais se distingue tomando por base o fato de se tratar de ação pessoal ou real, ou o de correr entre presentes e ausentes. Como o prazo prescricional mais longo é o de 10 anos, previsto no art. 205, ou se considerará que o prazo de prescrição da ação para reaver o bem é este mesmo ou - similarmente ao Min. Carlos Velloso e à Profa. Lúcia Valle Figueiredo, precitados - se adotará o prazo de 15 anos, que é o da usucapião, independentemente de justo título e boa-fé, conforme o art. 1.238, caput, do Código Civil.

Noutro giro, não é pacífico tal entendimento, acerca da tese de ser transmissível o direito de preferência do expropriado. ${ }^{7}$ Para Celso Antônio Bandeira de Mello (2009, pág. 895), não obstante a disposição contrária do art. 520 do $\mathrm{CC}$, tal artigo de lei só se aplicam aos

\footnotetext{
${ }^{7} \mathrm{O}$ nunca assaz citado Sérgio Ferraz (ob.cit., pp. 126 e 127) anota que acolhem o entendimento de que é transmissível: Gama Cerqueira e A. Lemos da Fonseca, Hélio Moraes de Siqueira e Onofre Mendes Jr. Além destes, podem ser referidos: José Carlos de Moraes Salles (ob. cit., p. 731), Carlos Alberto Dabus Maluf (ob. cit., p. 272) e Régis Fernandes de Oliveira (ob. cit., p. 31). Negam a transmissibilidade, segundo o mesmo autor: Castro Nunes, Ebert Chamoun, Eurico Sodré, F. Whitaler, Hely Lopes Meirelles, Guimarães Menegale, Seabra Fagundes, Pontes de Miranda. A estes deve-se acrescentar Diógenes Gasparini (ob. cit., p. 447).
} 
casos de preferência voltados para o Direito Privado, os quais derivam de um acordo entre as partes, devendo, assim, nos casos de desapropriação, ser totalmente protegido o direito do expropriado que teve seu direito de propriedade extinto sem a existência dos fundamentos constitucionais que autorizam a desapropriação, senão vejamos:

Inclinamo-nos a entender que este dispositivo do Código Civil tem aplicação apenas aos casos de preferência ou preempção no Direito Privado, os quais derivam de um acordo entre as partes. Parece-nos que o superior interesse da ordem jurídica seja o de proteger o mais amplamente quem teve seu direito de propriedade extinto, sem que comparecessem ou persistissem os fundamentos constitucionais que justificam a desapropriação. Como o direito de preferência integra, por força de lei, o patrimônio jurídico do expropriado, não há porque reduzirlhe a disponibilidade sobre ele no negar-lhe a transmissibilidade.

Por fim, surge a seguinte indagação? Se o bem expropriado foi aplicado a uma finalidade pública e, posteriormente, foi dela desligado, persiste o direito do ex-proprietário de ser afrontado para readquiri-lo?

Visando responder à indagação, veja a manifestação de Celso Antônio Bandeira de Mello (2009, pág. 896):
"Ao nosso ver, tal direito só comparece quando o bem expropriado não foi aplicado a finalidade de interesse público. Se o foi, nem por isto terá de ficar perpetuamente vinculado a destino de tal ordem, pena de exsurgir direito do expropriado a ser afrontado em caso de ulterior desafetação e eventual alienação do bem".

Assim sendo, pode-se asseverar que o bem então desapropriado não deverá estar vinculado ad perpetuam a um destino público, uma vez que o Poder Público tem o dever de solucionar determinadas necessidades públicas em dado tempo e lugar, segundo as exigências atuais da sociedade. Portanto, se cumpre as normas constitucionais e legais aplicáveis ao instituto da desapropriação, não há que se falar em lesão aos direitos do expropriado.

\section{Consequências Jurídicas da Tredestinação}

\section{Ilícita}

Acerca das consequências jurídicas da tredestinação ilícita, mister faz-se salientar que a jurisprudência pátria são uníssonas no reconhecimento do direito da parte que foi despojada de sua propriedade de reivindicá-lo judicialmente, veja-se: 
PERDAS E DANOS MATÉRIA DE DIREITO RECURSO

ESPECIALPROVIDO.

Cuida-se de ação ordinária de retrocessão, com pedido alternativo de indenização por perdas e danos, contra o Município de Maria da FéMG, ao fundamento de que parte da área expropriada não foi aplicada à qualquer finalidade pública.

(...)

In casu, porém, do exame acurado dos autos ficou demonstrado o desvio de finalidade de parcela do bem expropriado, que restou em parte abandonado, foi destinado a pastagens e à plantação de hortas, sem restar caracterizada qualquer destinação pública.

Como bem ressaltou o $\mathrm{R}$. Juízo de primeiro grau, "pelo exame da prova coligada nos presentes autos, entendo-se esta pelo laudo pericial e depoimentos testemunhais, vê-se que, de fato a área remanescente do imóvel desapropriado não foi utilizada pelo Poder Público, ou seja, àquela área não fora dada destinação pública, ainda que diversa da que ensejou 0 processo expropriatório".

No mesmo diapasão, o d. Parquet estadual concluiu que se caracteriza, "claramente, o desvio de finalidade na conduta do Administrador Público que, além de desapropriar área infinitivamente maior do que a efetivamente utilizada, ainda permitiu que particulares dela usufruíssem, prejudicando, à evidência, o direito dos autores".

Este signatário filia-se à corrente segundo a qual a retrocessão é um direito real.
$\mathrm{Na}$ espécie, contudo, determinar a retrocessão da parte da propriedade não destinada à finalidade pública, nesta via extraordinária, em que não se sabe seu atual estado, seria por demais temerário. Dessa forma, o município recorrido deve arcar com perdas e danos, a serem calculados em liquidação por arbitramento.

(...)

Recurso especial provido em parte, para determinar a indenização por perdas e danos da área de $44.981 \mathrm{~m} 2$, que não foi aplicada a qualquer finalidade pública. (REsp. 570483/MG, Relator (a) Ministro Franciulli Netto, Segunda Turma, DJ: 09/03/2004).

Nesse diapasão, conclui-se que a doutrina brasileira repudia com veemência a desapropriação praticada com desvio de finalidade, ato que abre ao expropriado a possibilidade jurídica de valer-se do instituto da retrocessão, anteriormente explanado, ou exercitar do direito de preferência, também já explicitado em tópico anterior, conforme lições de José dos Santos Carvalho Filho (2009, pág. 838), in verbis:

O Poder Público procede à desapropriação e ultima o respectivo processo, pagando a devida indenização. Introduzido o bem no patrimônio público, o expropriante não concretiza a destinação do bem na forma como se havia manifestado anteriormente, inclusive através da expressa 
referência a essa destinação no decreto expropriatório. A hipótese, portanto, demonstra desinteresse superveniente do Poder Público pelo bem que desapropriou, ou, se preferir, pela finalidade a que se destinava a desapropriação. É essa a situação que gera a retrocessão, pois o expropriante passa a ter a obrigação de oferecer ao exproprietário $\quad \mathrm{o}$ bem desapropriado, reembolsando-se do valor que pagou a este a título de indenização.

Tais posicionamentos doutrinário e jurisprudencial justificam-se uma vez que não obstante a discricionariedade do Poder Público acerca das possibilidades constitucionais para dar cabo à desapropriação pretendida, o fato é que jamais poderá se afastar de tais pressupostos constitucionais, sob pena de configurar abuso de poder.

\section{DEMORA NA UTILIZAÇÃO DO BEM}

A demora e a inércia na utilização do bem pelo expropriante não significa, por si só a desistência da desapropriação, não gerando, ao expropriado o direito à retrocessão. A inação deve estar claramente caracterizada, ou seja, a situação da desistência do expropriante em utilizar o bem para uma finalidade pública deve ser cristalina, a ponto de não haver contestação.

Portanto, para restar caracterizada a tredestinação ilícita, não basta a simples alegação pelo expropriado de não-utilização do bem expropriado, sendo, pois, exigida a demonstração inequívoca da intenção do expropriante de não utilizar o terreno expropriado, como ocorre no caso de venda ou doação a terceiros.

\section{CONCLUSÃO}

A Carta Magna garante o direito à propriedade (art. $\left.5^{\circ}, \mathrm{XXII}\right)$, porém, assegura ao Estado o poder de retirá-la pela desapropriação (art. $\left.5^{\circ}, \mathrm{XXIV}\right)$, que é o procedimento administrativo no qual o Poder Público retira de alguém de seu direito de propriedade compulsoriamente, adquirindo-o mediante indenização que normalmente é prévia, justa e em dinheiro, sendo seus fundamentos $\mathrm{o}$ interesse público, a necessidade pública ou o interesse social, ou como pena pela não utilização do bem nos termos de sua função social.

Ocorre a tredestinação lícita quando mantida a finalidade de interesse público o Poder Público dá ao bem desapropriado destino diverso do inicialmente planejado, e, a tredestinação ilícita quando o Poder Público transfere a terceiro o bem desapropriado ou pratica desvio de finalidade, permitindo que alguém se beneficie da utilização, reconhecendo-se ao expropriado o direito a uma satisfação jurídica diante de tal fato. 
Pois bem, após pesquisa acerca do instituto da tredestinação, sobretudo da tredestinação ilícita, conclui-se que não obstante a discricionariedade do Poder Público acerca das possibilidades constitucionais para dar cabo à desapropriação pretendida, o fato é que jamais poderá se afastar de tais pressupostos constitucionais, sob pena de configurar abuso de poder com consequente desvio de finalidade.

Diante de tal situação, abre-se ao expropriado o direito de exigir de volta o seu imóvel do Poder Público pelo preço atual da coisa, por intermédio do instituto da reversão, ou, alternativamente o exercício do direito de preferência, pleiteando perdas e danos caso o expropriante aliene o bem sem oferecer ao expropriado para que exerça seu direito de prelação, sendo que somente é possível o exercício do direito de retrocessão quando é dado ao bem outra destinação que não seja de interesse público.

Finalmente, conclui-se que a doutrina e os tribunais pátrios de forma uníssona defendem veementemente a mantença do interesse público em todo ato de desapropriação intentado pelo Poder Público, evitando-se o abuso de poder e atitudes contrárias aos princípios que norteiam a Administração Pública, sobretudo os princípios da legalidade, moralidade e imparcialidade que devem orientar o gestor público em todas as suas decisões.

\section{Referências}

ALEXANDRINO, Marcelo. PAULO, Vicente. Direito Constitucional Descomplicado. $4^{\text {a }} \mathrm{Ed}$. São Paulo: Método, 2009.

ALEXANDRINO, Marcelo. PAULO, Vicente. Direito Administrativo Descomplicado. $18^{\mathrm{a}}$ Ed. São Paulo: Método, 2010.

BANDEIRA DE MELLO, Celso Antônio. Curso de Direito Administrativo. $26^{\text {a }}$ Ed. São Paulo: Malheiros, 2009.

BRASIL. Decreto-lei. 20.910 de 06 de janeiro de 1932.

de 1941.

. Decreto-lei no 3.365 , de 21 de junho

. Constituição da República

Federativa do Brasil de 1988.

da Cidade.

Lei Federal no 10.257/01- Estatuto

Lei Federal 10.406 de 10 de janeiro de 2002. Código Civil.

Superior Tribunal de Justiça. In:

Resp. 814.570 - Rel. Mauro Campbell Marques $2^{a}$ Turma DJ: 17/08/2010.

In: Resp. 819.191/SP - Rel. José

Delgado $1^{\text {a }}$ Turma DJ: 22/05/2006.

In: Resp.975.599/SP- Rel. Humberto Martins $2^{a}$ Turma DJ: 07/03/2008.

In: Resp. 647.340/SC- Rel. João

Otávio de Noronha $2^{\text {a }}$ Turma DJ:06/04/2006. 
In: Resp. 868.120/SP - Rel. Luiz Fux

$1^{\text {a }}$ Turma DJ: $27 / 11 / 2007$.

In: Resp. 570.483/MG- Rel. Franciulli

Netto $2^{\text {a }}$ Turma DJ: 09/03/2004.

In: Resp. 1134493/MS- Rel. Herman

Benjamim 2a Turma DJ:15/12/2009.

FILHO, José dos Santos Carvalho. Manual de

Direito Administrativo. $21^{\text {a }}$ Ed. Rio de

Janeiro: Lumen Juris, 2009.

MARINELA, Fernanda. Direito

Administrativo. $5^{\text {a }}$ Ed. Rio de Janeiro:

Impetus, 2011.

MEIRELLES, Hely Lopes. Direito

Administrativo Brasileiro. $35^{\mathrm{a}}$ Ed. São Paulo:

Malheiros, 2009.

MORAES, Alexandre. Constituição do Brasil

Interpretada e legislação constitucional. São

Paulo: Atlas, 2002. 